\title{
STUDIES ON THE ECOLOGY AND FERTILITY PROPERTIES OF SOME DESERT SOILS IN EGYPT
}

Zaghloul, A. K. 1; Asmaa A. Shata ${ }^{2}$; M. F. Attia ${ }^{3}$ and E. A. M. Khalifa ${ }^{4}$

${ }^{1}$ Sand Dunes Dept., Desert Research Center (DRC), Cairo

${ }^{2}$ Pedology Dept., Desert Research Center (DRC), Cairo

${ }^{3}$ Soil Fertility and Microbiology Dept., Desert Res. Center (DRC), Cairo

${ }^{4}$ Plant Ecology and range Dept., Desert Research Center (DRC), Cairo

\begin{abstract}
A pilot experiment was adopted in the period July 2011 to June 2012 by the Desert Research Center, in collaboration with Agricultural Research for Development Fund (ARDF), Ministry of Agriculture and Land Reclamation. The eco-physiological responses of the sand dune vegetation were studied in relation to climatic and microedaphic factors at three locations i.e. El Arish, North Sinai, (Garada village), Siwa Oasis (Khamisa) and East of Cairo (El Gabel Al Asfer). Besides, the soil fertility status of the investigated regions was studied through evaluating soil physical and chemical properties.

From vegetation studies, it that was concluded that El Arish region was semi fixed (more or less stabilized) dune area. It is dominated by Artemisia monsperma. In Siwa Oasis, the phreatophytic species Alhagi maurorum (=A. graecoarum) dominates the extensions where sand embankments are mostly stabilized as well as extensions veneered with sand sheets. With regard to East Cairo (El Gabal El Asfar areas) a total of 25 species ( 20 perennials and 5 annuals) were recorded. Sand dune habitat in the study area is divided into three microhabitats namely: Interdunal, dune crest, and leeward habitat.

Regarding soil fertility status of the three studied regions, data indicated that the soil texture is sand in all regions, but it ranges from medium to coarse in Siwa Oasis (Khamisa), medium in East Cairo (El-Gabal El-Asfar) and very fine in El-Arish (Garada). The soil saturation percent (SP) and total organic matter (O.M.) content are low and the available macronutrients content (NPK), is not sufficient for the plant requirements to grow in all regions. Available micronutrients content ( $\mathrm{Fe}, \mathrm{Zn}$ and $\mathrm{Cu}$ ), in surface layer is at lower or critical (marginal) levels in soils of both Garada and Khamisa regions, whereas, in El-Gabal El-Asfar, available micronutrients are sufficient for plant requirement. Garada soils are moderately alkaline, free saline and rarely slightly, varied from non to slightly calcareous, the cationic and the anionic sequences are as follows: $\mathrm{Mg}^{++}>\mathrm{Ca}^{++}>\mathrm{Na}^{+}>\mathrm{K} ; \mathrm{HCO}_{3}>\mathrm{SO}_{4}{ }^{--}>\mathrm{Cl}^{-}$. Khamisa soils are slightly to moderately alkaline, slightly to extremely saline, moderately calcareous, the cationic and the anionic sequences are as follows: $\mathrm{Na}^{+}$and/or $\mathrm{Mg}^{++}>\mathrm{Ca}^{++}>\mathrm{K}^{+} ; \mathrm{Cl}^{-}>\mathrm{SO}_{4}^{--}>$ $\mathrm{HCO}_{3}{ }^{-}$. El-Gabal El-Asfar soils are free saline, non calcareous, the cationic and the anionic sequences are as follows: $\mathrm{Mg}^{++}>\mathrm{Ca}^{++}>\mathrm{Na}^{+}>\mathrm{K}^{+} ; \mathrm{HCO}_{3}{ }^{-}>\mathrm{Cl}^{-}>\mathrm{SO}_{4}^{--}$.

Statistical analysis indicated that significant differences were observed between the under studied three regions and each other in the content of organic matter (O.M.) and available macro- and micro-nutrients in the soil surface layer. The relationship between $\mathrm{pH}, \mathrm{EC}$, cations and anions, in soil saturated paste extract of the surface layer in the three studied regions, was showed through multiple correlations.
\end{abstract}

Keywords: Eco-physiological responses, Sand dune vegetation, Climatic and microedaphic, soil fertility status, soil physical and chemical properties. 


\section{INTRODUCTION}

Egypt is considered one of the extremely arid countries in north east Africa, between latitudes $22^{\circ}$ and $32^{\circ} \mathrm{N}$ and longitudes $25^{\circ}$ and $37^{\circ} \mathrm{E}$ covering an area of about one million $\mathrm{km}^{2}$ which takes the near of square. The aeolian sands represent one of the most common land forms. It covers about $16.5 \%$ of the whole country. Morphologically, these forms are subdivided into sand seas, isolated dunes, dune fields, sandy plains and sheets. The distribution of such accumulations is shown in Fig. (1) and they cover an area of $4,000 \mathrm{~km}^{2}$ in the northern portion of Sinai peninsula, 5,000 $\mathrm{km}^{2}$ in north western coast, $1,000 \mathrm{~km}^{2}$ in El-Qatara and Siwa depressions, $4,500 \mathrm{~km}^{2}$ in middle and southern depression, $135,000 \mathrm{~km}^{2}$ the Great Sand sea in the western desert, $500 \mathrm{~km}^{2}$ to the east of delta and $3,000 \mathrm{~km}^{2}$ in ElFayoum and Wadi El-Rayan (Embabi, 2000).

Sinai Peninsula is of special ecological interest because of its variable environment, release landscape, and distinctive flora and its uniqueness and contrast (Zahran \& Willis, 2009). It is covered in its north western extensions mostly by sand dunes, expect for some mountains and hills where the bare rock is exposed. Vast areas of sand dunes are not vegetated except for a sparse cover in the innerdune areas. The dunes of a complex type, are consist of a large dune on which dune lets are superimposed (Tsoar, 1995, Danin, 1983 and Ali, 2004).

Zahran (1972) classified the vegetation of Siwa Oasis into four ecosystems namely, reed swamps, salt marshes, sand formations and gravel desert. Sand formations are dominant feature in the landscape of the Oasis. Such sand formations are formed from the aeolian deposits which form different types including sand sheets, sand plains, sand bars as well as different characteristic shapes of sand dunes.

The concerned region of Al Gabel al Asfar, East of Cairo lies in the extension east of the Nile Delta. It is in the northern extension of the Eastern Desert. The study area comprises two main habitat types namely Sand dunes, and newly reclaimed lands. According to Misak \& El- Ghazawy (1989) and Misak \& Draz (1997), sand dunes in the two sides of the Nile Delta are classified as slightly migrating duns (i.e: move less than $5 \mathrm{~mm} / \mathrm{year}$ ). The vegetation of sand dune habitat is sparse open vegetation restricted to the interdunal depressed areas e.g: , Alhagi graecorum and Kochia muricata.

With respect to Khamisa, it lies in Siwa Oasis which is located in the Western Desert of Egypt. Siwa Oasis is located on the northern edge of the Great Sand Sea, one of the largest sand areas in the world. Siwa Oasis has a length of about $75 \mathrm{~km}$ and a width varying between 5 and $25 \mathrm{~km}$ with a total area of about $1088 \mathrm{~km}^{2}$. At Siwa Oasis heavy investments have been directed to turn vast regions of the desert land into green productive areas. However, due to the miss-use of irrigation water in many of such regions, water logging and salinity problems become more serious against development.

The current research aims to evaluate the ecological, physical and chemical properties for desert soils in Egypt (i.e. Garada village (North Sinai), Elberkah, El Gabel Al Asfer (East of Cairo) and Khamisa, Siwa Oasis, (western desert of Egypt). 


\section{MATERIALS AND METHODS}

A pilot experiment was adopted in the period July 2011 to June 2012 by the Desert Research Center, in collaboration with the Agricultural Research Center for Development Fund (ARDF), Ministry of Agriculture and Land Reclamation. The eco-physiological responses of the sand dune vegetation were studied in relation to climatic and micro-edaphic factors at three locations, i.e. Garada village - North Sinai, Siwa Oasis and Elberkah, El Gabel Al Asfer East of Cairo. Besides, the fertility status of the soil of the investigated regions was studied through evaluating soil physical and chemical properties.

\section{Determinations}

A- Climate studies: Means of the climatic normal of Meteorological Stations, the nearest portion from the study area, during the period 2000-2010 are given.

\section{B- Vegetation analysis and plant sampling:}

Six sites were selected; each site is $400 \mathrm{~m}^{2}(20 \mathrm{~m} \times 20 \mathrm{~m})$. The list of species of each site were recorded and identified, following Täckholm (1974) and updated according to Bolous (1995). Species in each site are organized into six categories as follow: Dominant, Abundant, Very common, Common, Rare, and Very rare due to their density and cover in each site.

\section{C-Soil sampling and analysis:}

To determine physical and chemical properties for soil, five soil profiles were dug to $150 \mathrm{~cm}$ depth, unless hindered by bedrock or water table, in the three locations of the studied area (FAO 2006). Soil samples were taken from these soil profiles for the laboratory analyses.

The collected soil samples were dried, crushed and sieved through a 2-mm sieve. The coarse size; gravels and stones, were determined volumetrically, while the fine size was taken and kept for physical and chemical analyses.

The routine analyses including soil $\mathrm{pH}$, electrical conductivity, were estimated in the soil paste extract (Bashour and Sayegh 2007). The total calcium carbonate was measured by treating the samples with $\mathrm{HCl}$ and the evolved $\mathrm{CO}_{2}$ was measured manometrically as followed by (USDA, 2004). The gravels content was measured by volume according to (USDA, 2004). The particle size distribution (size $<2 \mathrm{~mm}$ ) was carried out for sandy texture soils by dry sieving, (Piper, 1950), and for the soils of heavier textures by hydrometer method, (Gavlak et al., 2003). All data, concerning physical and chemical properties for soil surface layers of the three studied regions, were analyzed by SAS Institute (1996). Differences between mean values were determined with Duncan's Multiple Range Test at level 0.05. Multiple correlations between soil properties was determined at level 0.05 and 0.01 .

\section{Ecological studies:}

\section{RESULTS AND DISCUSSION}

\section{A. Climate studies:}

Data in Table1 showed that during ten years (i.e. 2000-2010) the average of wind speed, temperatures and rainfall amounts were $8.2 \mathrm{k} / \mathrm{h}$, 
$20.8^{\circ} \mathrm{C}$ and $9 \mathrm{~mm}$ at El-Arish area, $7.3 \mathrm{k} / \mathrm{h}, 22.9^{\circ} \mathrm{C}$ and $1.0 \mathrm{~mm}$ at Siwa oasis and $13.2 \mathrm{k} / \mathrm{h}, 22.5^{\circ} \mathrm{C}$ and $1.4 \mathrm{~mm}$ at East Cairo, respectively.

Table (1). Some climate parameters of EL-Arish area, Siwa oasis and

\begin{tabular}{|c|c|c|c|c|c|c|c|c|c|}
\hline \multirow{2}{*}{\begin{tabular}{|l} 
Location \\
Unit
\end{tabular}} & \multicolumn{3}{|c|}{ EL-Arish area } & \multicolumn{3}{|c|}{ Siwa oasis } & \multicolumn{3}{|c|}{ East Cairo } \\
\hline & $\begin{array}{c}\text { Wind } \\
\text { speed } \\
\mathrm{K} / \mathrm{h}\end{array}$ & $\begin{array}{l}\text { Temp. } \\
\left({ }^{\circ} \mathrm{C}\right)\end{array}$ & $\begin{array}{l}\text { Rain } \\
(\mathrm{mm})\end{array}$ & $\begin{array}{c}\text { Wind } \\
\text { speed } \\
\mathrm{K} / \mathrm{h}\end{array}$ & $\begin{array}{c}\text { Temp. } \\
\left({ }^{\circ} \mathrm{C}\right)\end{array}$ & $\begin{array}{l}\text { Rain } \\
(\mathrm{mm})\end{array}$ & $\begin{array}{c}\text { Wind } \\
\text { speed } \\
\text { K/h }\end{array}$ & $\begin{array}{c}\text { Temp. } \\
\left({ }^{\circ} \mathrm{C}\right)\end{array}$ & $\begin{array}{l}\text { Rain } \\
(\mathrm{mm})\end{array}$ \\
\hline \begin{tabular}{|l} 
JANUARY \\
\end{tabular} & 9.7 & 13.5 & 29.0 & 7.4 & 13.5 & 1.0 & 12.2 & 14.9 & 3.8 \\
\hline FEBRUARY & 10.2 & 14.6 & 19.0 & 9.1 & 15.0 & 3.0 & 13.3 & 16.0 & 3.2 \\
\hline MARCH & 9.4 & 16.9 & 15.0 & 9.6 & 18.7 & 0.5 & 13.9 & 19.0 & 3.2 \\
\hline APRIL & 10.0 & 19.5 & 3.0 & 9.7 & 22.7 & 1.0 & 15.5 & 22.3 & 0.5 \\
\hline MAY & 8.6 & 22.0 & 6.0 & 8.7 & 26.3 & 2.0 & 15.3 & 25.7 & 0.0 \\
\hline JUNE & 7.3 & 24.9 & 0.0 & 7.3 & 29.6 & 0.0 & 14.6 & 28.5 & 0.0 \\
\hline JULY & 7.0 & 27.1 & 0.0 & 6.7 & 31.2 & 0.0 & 12.9 & 29.6 & 0.0 \\
\hline AUGUST & 6.2 & 27.6 & 0.0 & 6.2 & 31.1 & 0.0 & 12.7 & 29.6 & 0.0 \\
\hline SEPTEMBER & 6.6 & 26.0 & 0.0 & 6.1 & 29.1 & 0.5 & 13.2 & 28.1 & 0.0 \\
\hline OCTOBER & 6.8 & 23.4 & 9.0 & 5.2 & 24.4 & 1.0 & 12.2 & 24.9 & 0.3 \\
\hline NOVEMBER & 7.6 & 19.0 & 5.0 & 5.0 & 18.8 & 1.0 & 10.6 & 20.3 & 1.5 \\
\hline DECEMBER & 9.0 & 15.2 & 22.0 & 6.1 & 14.8 & 2.0 & 11.6 & 11.6 & 3.8 \\
\hline
\end{tabular}

Source: Nation Environmental satellite, data, and information service (NESDIS)

Data in (Table, 2 and Fig.1) show the wind direction and the wind rose of the study areas. The percentages of dominant direction were North in both ELArish area (22\%) and East Cairo (33\%), whereas, it was West and North West in Siwa oasis (20\%).

Table (2). Weighted mean of wind directions in the study area (January

\begin{tabular}{|l|l|l|l|c|c|c|c|c|c|}
\hline Locations 2000 - December 2010) \\
\hline \hline EL-Arish area & Directions* $^{*}$ & N & NE & E & SE & S & SW & W & NW \\
Siwa Oasis & 22 & 4 & 3 & 12 & 17 & 12 & 11 & 19 \\
East Cairo & $\%$ & 16 & 14 & 16 & 6 & 4 & 4 & 20 & 20 \\
& & 33 & 20 & 8 & 2 & 4 & 6 & 10 & 16 \\
\hline
\end{tabular}

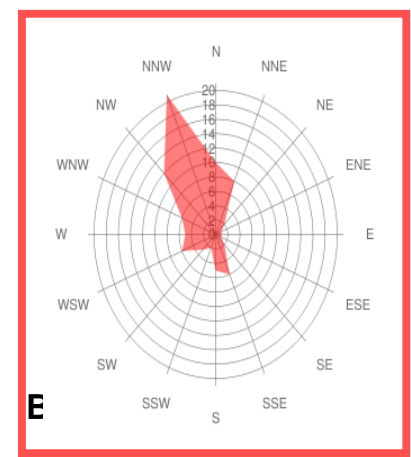

Wind rose of El-

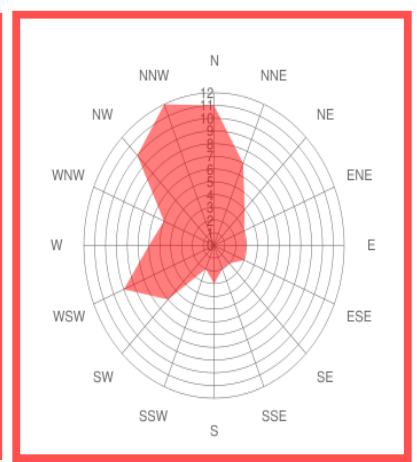

Wind rose of Siwa

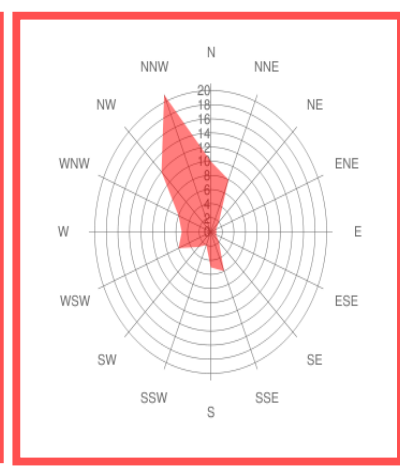

Wind rose in East

Fig. (1). Wind rose of the study areas 


\section{a. EL-Arish region}

Table 3 and Fig. 2 show list of species recorded in the study area showing their distribution, growth forms and status at EL-Arish areas as follows:

Site (1): This site is located in the semi fixed (more or less stabilized) dune area. It is dominated by Artemisia monsperma which form small sandy hummocks $50 \mathrm{~cm}$ sized. The most common associated species are: Zygophyllum album which forms small sand hummocks; Echinops spinosissimus and Fagonia shemiperi. Whereas, Panicum turgidum, Atractylis carduus, and Heliotropium digynum are rare species between the nebkhas of the previous species. There are some species of rare occurance in the margin of the waste water marshes such as: Kochia muricata \& Tamarix nilotica, while Cyperus laevigatus \& Phragmites australis are rare inside the marshes.

Site (2): The substrate of this site is consisting of coarse sand mixed with gravels. This structure supports Zygophyllum album rather than Artemisia monsperma which require high amount of accumulated sand. The most common associated species is Fagonia shemiperi. Common species within this site is Echinops spinosissimus, here as, Heliotropium digynum is a rare species.

On the other hand, Atractylis carduus and Tamarix nilotica are occasional between the hummocks of Zygophyllum album and the margin of waste marshes, respectively.

Site (3): Compared with other sites, this site is slightly elevated and characterized by the prevailing of sand. This feature is favor for the domination of Artemisia monosperma. Three new rare species were recorded in this site namely: Stipagrostis ciliata, Thymeleae hirsuta, and Neurada procumbens. There are two species common in the previous sites and still present in this site but in rare occurence namely: Zygophyllum album, and Echinops spinosissimus.

Site (4): This site is of a dense cultivated cover compared to the other sites (cover percentage about $40 \%$ ) due to the presence of olive cultivars in the northern direction which acts as shelterbelt preventing the mobility of the sandy substrate and accordingly, presence of the dense vegetation.

The dominant species is Artemisia monosperma. The abundant species is Zygophyllum album. While, Echinops spinosissimus is very common; Moltkiopsis ciliata is common; and Malva parviflora is very rare.

Site (5): This site is similar to the previous one but, it is surrounded by two fences in the northern direction and cultivated with Eucalyptus spp. and Gazwarina spp. the second fence in the opposite southern direction and cultivated with Hibiscus rosa-chinasa. The plants of the two fences are irrigated with waste water. There are some annuals appear in the shaded places around the fences and in the infiltration places of the irrigation pipes. There are some edible species which are distributed through the waste water such as: tomatoes, cucumber, and purslance (Portulaca oleracea). 
Zaghloul, A. K. et al.

Table (3). Vegetation analysis of the study areas at EL-Arish

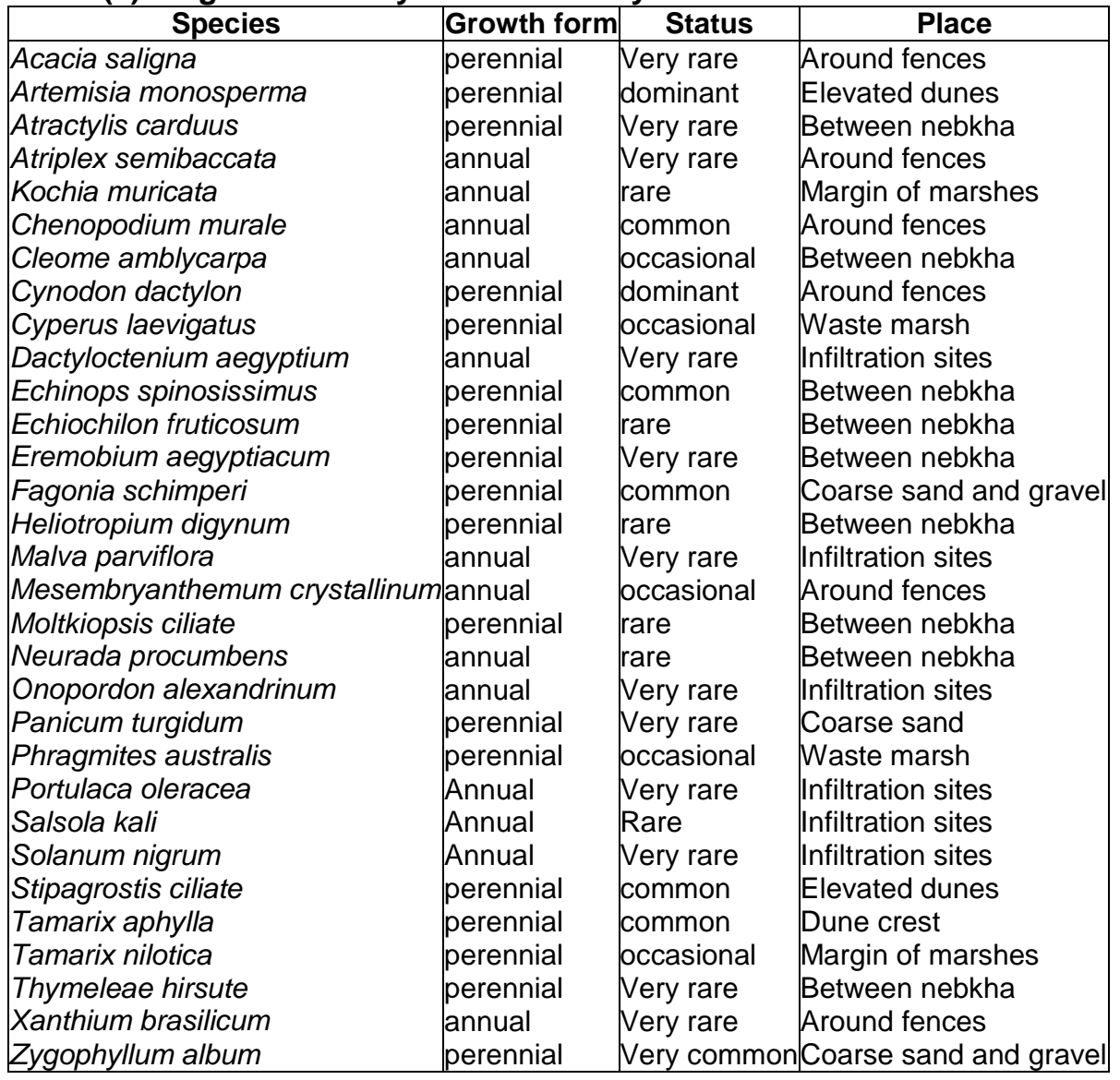

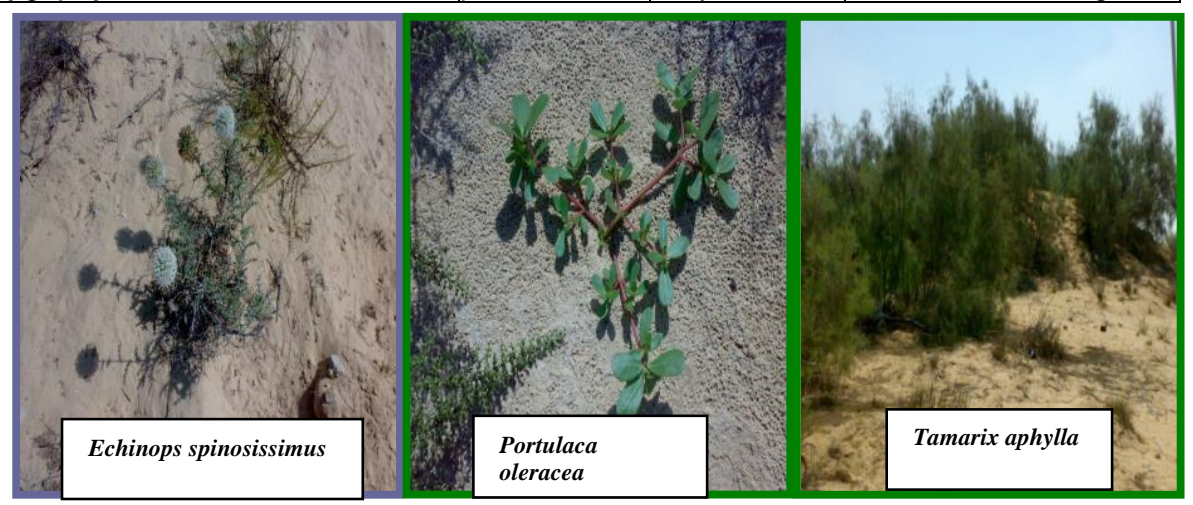

Fig (2). Some plant species at El- Arish area

The dominant species of this site is Artemisia monsperma in the elevated sand formation, Cynodon dactylon around the fences. The most common annuals are: Mesembryanthemum crystallinum, Xanthium 
brasilicum, and Kochia muricata in the dry elevated sites around the fences. While, Atriplex semibaccata is very rare in the same sites. There are some species appears between hummocks of Artemisia monsperma especially in the infiltration sites namely: Cleome amblycarpa, Chenopodium murale, Dactyloctenium aegyptium. There are two rare species present between the sandy hummocks in the dry areas namely: Echiochilon fruticosum, and Stipagrostis ciliata.

Site (6): In spite of the presence of three protection fences around this site, presence of Tamarix aphylla tress in the northern direction, presence of metallic wall, and fence of Eucalyptus spp., the plant cover is very poor but has the highest number of species. This may be due to the erosion effects resulted from the activities of the station.

The dominant species is Cynodon dactylon (around the fence), whereas, Artemisia monosperma, Moltkiopsis ciliata, Echiochilon fruticosum, Heliotropium digynum, Stipagrostis ciliata, Cleome amblycarpa, Neurada procumbens, Salsola kali, Eremobium aegyptiacum , and Acacia saligina are rare within this site. On the other hand, Solanum nigrum, and Onopordon alexandrinum species are rare in the infiltration areas.

Results indicated that the high representation of annual species in the sand dune habitat of El- Arish area may be due to several factors such as high percentage of fine ingredients, moisture content of the soil and the mild prevailing climate of this area .Also, the increase of maritime influence has great impact on the vegetation composition and nature of the characteristic species in north Sinai. Results of the present work agreed with those of ElGhareeb (1991) and Abd El- Fattah and Dahmash (2002).

\section{b. Siwa Oasis (Khamisa)}

Data in Table 4 and Fig. 3 show list of species recorded in the study area showing their distribution growth forms and status at Siwa Oasis as follows:

Table (4). Vegetation analysis of the study areas at Khamisa (Siwa Oasis)

\begin{tabular}{|l|l|l|l|}
\hline Species & \multicolumn{1}{|c|}{ Stems } & Growth form & \multicolumn{1}{|c|}{ Place } \\
\hline Zygophyllum album & Perennial & Very common & sand hummocks \\
Cornulaca monacantha & Perennial & Very abundant & Between nebkha \\
Stipagrostis scoparia & Perennial & Rare & Elevated dunes \\
Alhagi maurorum & Perennial & Abundant & Inter dunes \\
Cistanche tubulosa & Perennial & Very rare & Road side \\
\hline
\end{tabular}

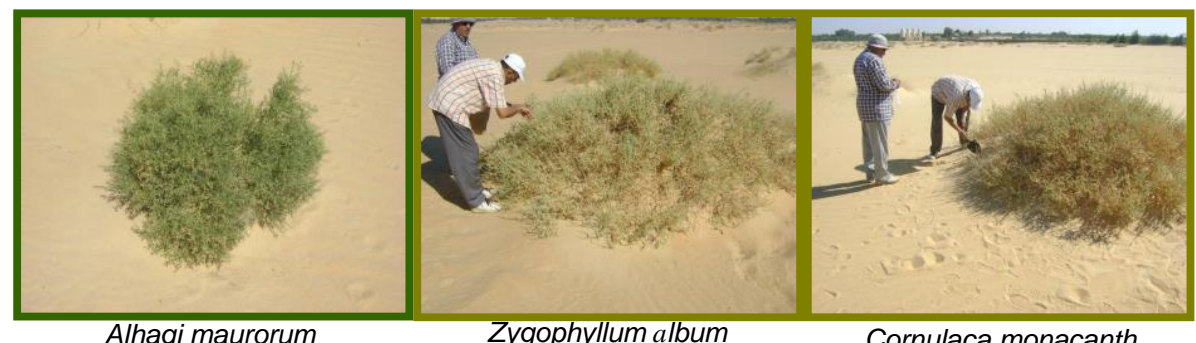

Fig (3). Some plant species at Siwa 
Mobile sand dunes are dominated by Cornulaca monacantha and associated by Zygophyllum album as a very common species.

The phreatophytic species Alhagi maurorum (= A. graecarum) dominates the extensions where sand embankments are mostly stabilized as well as extensions veneered with sand sheets. Again, Zygophyllum album (stem and leaves succulent perennial plant) is the very common associated species. Consequently, the vegetation of Siwa Oasis was very limited in diversity, number of individuals and distribution. These results are in agreement with those of Ayyad and Fakhry (1994 \& 1996) and El- Khouly (2001) where they found that diversity is greater in the plant communities on stabilized sand dunes than those found on the active and partially stabilized sand dunes.

\section{c. East Cairo (El Gabal El Asfar areas):}

Data in Table 5 and Fig. 4 show list of species recorded in the study area showing their distribution, growth forms and status at El Gabal El Asfar area as follows:

A total of 25 species ( 20 perennials and 5 annuals) were recorded at El Gabal El Asfar in the two studied habitats (Table 5 and Fig.4).

Most of species are distributed in the Canal bank habitat. The main habitats and the floristic composition for each are discussed below:

\section{Sand dune habitat:}

Sand dune habitat in the study area is divided into three microhabitats namely: Interdunal habitat, Dune crest, and Leeward habitat.

* Interdunal habitat: This habitat is close to the water table and far from the effects of the strong wind. Vegetation in this sites is relatively dense consists of Alhagi graecorum (dominant), Sarococornia fruticosa (abundant) and one individual of Calotropis procera and Echiochilon fruticosum, both of them are (very rare).

${ }^{*}$ Crest habitat: This habitat is occupied with hummock forming species. The dominant species is Haloxylon salicornicum, whilst, the very common species is Cornulaca monacantha. On the other hand, Heliotropism digynum is very rare associated species.

*Leeward habitat: This habitat is favorable for the domination of pure community of Sarococornia fruticosa species.

Newly Reclaimed lands: The floristic composition of this habitat is similar to the Nile valley assemblages. It can be divided into: Follow lands, Canal bank habitat, cultivated lands and road side.

* Follow lands habitat: most of the species growing in this habitat are salt tolerant species. It is dominated by Tamarix nilotica, followed by Conyza dioscoridis (very common), Kochia muricata (common), Kochia indica (common), Imperata clynidrica (common), Cynodon dactylon (very common), Phoenix dactylifera ( rare) and Cyperus rotendous (rare).

* Canal Bank habitat: Vegetation of this habitat is the most dense and diverse one among other habitats of newly reclaimed lands. The dominant species is Phragmites australis. The main associated species are: Cynanchum acutum subsp. acutum (abundant) which is climbing on Phragmites australis; Saccharum spontaneum var. aegyptiacum (very common) and Cyperus articulatus (occasional). 
Table (5). List of species recored in the study area, El Gabal El Asfar.

\begin{tabular}{|c|c|c|c|}
\hline Species & Type & Status & Place \\
\hline Alhagi graecorum & Perennial & Dominant & Road side, inter dunes \\
\hline Bssia indica & Annual & Common & Follow, cultivated lands, road side \\
\hline Bssia muricata & Annual & Common & Follow, cultivated lands, road side \\
\hline Calotropis procera & Perennial & very rare & Interdunes \\
\hline Conyza dioscoridis & Perennial & very common & Follow lands \\
\hline Cornulaca monacantha & Peren & very common & Dune crest \\
\hline Cynanchum acutum sub & Perennial & A bundant & Canal bank \\
\hline Cynodon dactylon & Perennial| & very common & Follow, cultivated lands \\
\hline Cyperus articulatus & Perennial| & occasional & Canal bank \\
\hline Cyperus rotundus & Perennial| & rare & Follow land, cultivated lands \\
\hline Dactyloctenium aegyptium & Annual & occasional & Cultivated lands \\
\hline Datura innoxia & Perennial & occasional & Road side \\
\hline Echiochilon fruticosum & Perennial & very rare & Interdune \\
\hline $\begin{array}{l}\text { Haloxylon salicornicum } \\
\text { Heliotropium diqynum }\end{array}$ & $\left|\begin{array}{|l}\text { Perennial } \\
\text { Perennial }\end{array}\right|$ & Dominant & $\begin{array}{l}\text { Sand dune crest } \\
\text { Sand dune crest }\end{array}$ \\
\hline Imperata cylindrical & Poronnial & Common & Canal bank \\
\hline Phoenix dactylifera & $P$ & Irare & Follow lands \\
\hline Phragmites australis & Per & Dominant & Canal bank \\
\hline Sarcocornia fruticosa & Perennial & A bundant & Interdunes, Leeward \\
\hline Tamarix nilotica & Perennial & very commo & margin of Canal \\
\hline Tribulus terrestris & Annual & very rare & Road side \\
\hline $\begin{array}{l}\text { Withanin } \\
\text { Ziziphus }\end{array}$ & Perenni & occasional & Road side \\
\hline & & & \\
\hline
\end{tabular}

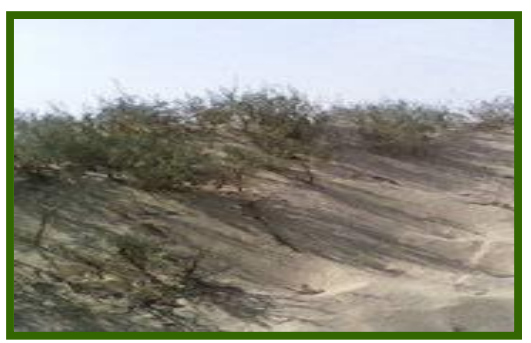

Saococornia fruticosa

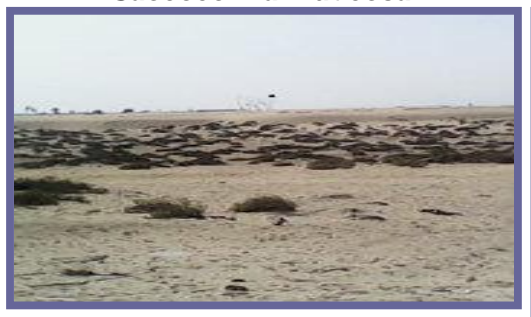

Saococornia fruticosa

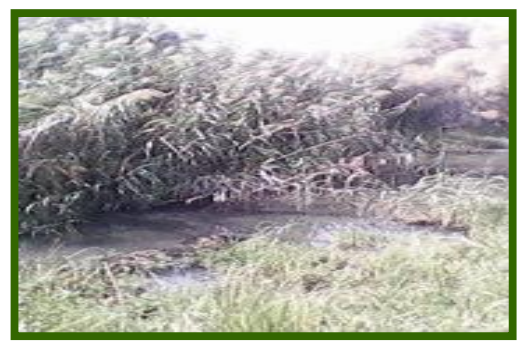

Phraamites australis

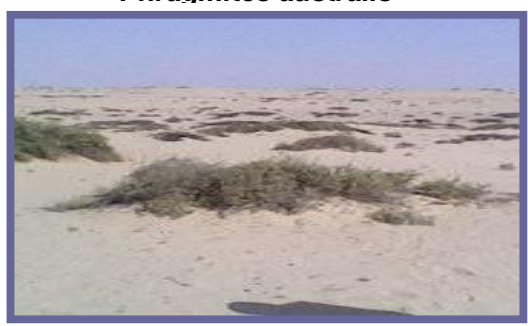

Haloxylon salicornuicum

Fig (4). Some plant species at El Gabal El Asfar

On the other hand, there are some species distributed at the margin of canal such as: Tamarix nilotica (very common), Alhagi graecorum (rare) and Imperata clyndrica (very common), as well as the edible plants distributed through the sanitary water such as: tomatoes, cucumber, and watermelon. 
* Cultivated lands: The sanitary treated water is used for the irrigation system for cultivation of oil plants (Jatropha spp). This field supports a lot of annuals such as: Solanum nigrum (rare), Cyperus rotendous ( very common), Dactyloctenium aegyptium (occasional), Kochia indica (occasional), Kochia muricata (common), and Cynodon dactylon (very common)

* Road side habitat: This habitat harbour 6 species. The dominant species is Kochia indica. The most common species is Cynodon dactylon, whereas, Withania somnifera and Ziziphus spina- christi and Datura innoxia are occasional species. On the other hand, the very rare species is Tribulus terrestris.

Generally, there are two main habitat types can be distinguished in the study area namely: Sand dunes and newly reclaimed lands. The floristic composition consists of 25 species. Most of them are perennials $80 \%$ and $20 \%$ annuals. The most diverse habitat is the newly reclaimed land (18 species). Whereas, the sand dune habitat contains 7 species. From the previous qualitative study we can conclude the following:

* It is advisable to encourage expansion of the cultivation of woody species such as Euclapytus ,Gazwarina spp, Acacia spp., Tamarix spp. and Prosopis spp.

* The development programmers should be directed toward agriculture instructions and combating pests.

* Edible vegetables and fruits as well as range plants should not be irrigated with sanitary water. These results are similar to those obtained by Hegazi et al (2002 \& 2005)

2. Physical and chemical soil properties and fertility status follows:

As shown in Tables (6, 7 \& 8), soil properties can be concluded as

a. El-Arish (Garada):

- $\quad$ The soils texture is very fine sand.

- $\quad$ Saturation percent (SP) was low where it ranged from 18.33 to $24.66 \%$ with an average of $21.89 \%$.

- The soils are moderately alkaline as $\mathrm{pH}$ values ranged from 7.83 to 8.26 with an average of 8.05 .

- The soils are free saline and rarely slightly saline as EC values ranged from 0.50 to $2.67 \mathrm{dSm}^{-1}$ with an average of $1.17 \mathrm{dSm}^{-1}$.

- The soils varied from none to slightly calcareous as $\mathrm{CaCO}_{3} \%$ ranged from 1.01-3.98 with an average of $1.46 \%$.

- The cationic and the anionic sequences are as follows:

${ }^{*} \mathrm{Mg}^{++}>\mathrm{Ca}^{++}>\mathrm{Na}^{+}>\mathrm{K}^{+} \quad{ }^{*} \mathrm{HCO}_{3}>\mathrm{SO}_{4}{ }^{-}>\mathrm{Cl}^{-}$

- Total organic matter (O.M.) content is low as it ranges from 0.188 to $0.288 \%$ with an average of $0.238 \%$.

- The available macronutrients content, in surface layer, is not sufficient for the plant requirements to grow; it ranged from 40.0-62.5, 2.22-5.51 and 43.4-65.8 $\mathrm{mgkg}^{-1}$ for $\mathrm{N}, \mathrm{P}$ and $\mathrm{K}$, respectively. 
J. Soil Sci. and Agric. Eng., Mansoura Univ., Vol. 3 (7),July 2012

Table (6). Soil physical properties of the three studied regions

\begin{tabular}{|c|c|c|c|c|c|c|c|c|}
\hline \multirow{2}{*}{ Region } & \multirow{2}{*}{ Profile No. } & \multirow{2}{*}{ Depth (cm) } & \multirow{2}{*}{$\begin{array}{l}\text { SP } \\
\%\end{array}$} & \multicolumn{4}{|c|}{ Gravel Grain size distribution \% } & \multirow{2}{*}{ Texture class } \\
\hline & & & & & C.S & M.S & F.S & \\
\hline \multirow{15}{*}{ 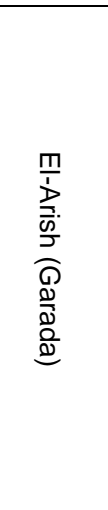 } & \multirow{3}{*}{1} & $0-50$ & 22.66 & 30.42 & 3.13 & 13.91 & 82.96 & Very fine sand \\
\hline & & $50-100$ & 22.33 & ----- & 1.04 & 29.3 & 69.66 & Very fine sand \\
\hline & & $100-150$ & 22.00 & ----- & 1.22 & 24.62 & 74.16 & Very fine sand \\
\hline & \multirow{3}{*}{2} & $0-50$ & 22.33 & 9.43 & 1.92 & 23.9 & 74.18 & Very fine sand \\
\hline & & $50-100$ & 24.66 & ----- & 0.35 & 21.17 & 78.48 & Very fine sand \\
\hline & & $100-150$ & 24.33 & ----- & 0.57 & 25.57 & 73.886 & Very fine sand \\
\hline & \multirow{3}{*}{3} & $0-50$ & 24.66 & $\begin{array}{l}----- \\
\end{array}$ & 0.5 & 17.69 & 81.81 & Very fine sand \\
\hline & & $50-100$ & 18.33 & ----- & 0.93 & 43.04 & 56.03 & Very fine sand \\
\hline & & $100-150$ & 19.00 & ----- & 0.29 & 32.06 & 67.65 & Very fine sand \\
\hline & \multirow{3}{*}{4} & $0-50$ & 21.66 & 5.8 & 1.00 & 30.81 & 68.19 & Very fine sand \\
\hline & & $50-100$ & 20.33 & ----- & 0.44 & 27.98 & 71.58 & Very fine sand \\
\hline & & $100-150$ & 21.00 & ----- & 0.33 & 26.95 & 72.72 & Very fine sand \\
\hline & \multirow{3}{*}{5} & $0-50$ & 21.66 & ----- & 1.00 & 30 & 69.00 & Very fine sand \\
\hline & & $50-100$ & 21.66 & ----- & 0.62 & 34.07 & 65.31 & Very fine sand \\
\hline & & $100-150$ & 21.66 & ----- & 1.55 & 38.12 & 60.33 & Very fine sand \\
\hline \multirow{20}{*}{ 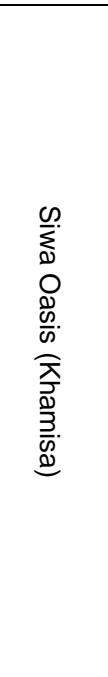 } & \multirow{4}{*}{1} & $0-30$ & 18.33 & ----- & 19.08 & 32.24 & 48.68 & Medium sand \\
\hline & & $30-60$ & 17.33 & ----- & 41.25 & 18.52 & 40.23 & Coarse sand \\
\hline & & $60-85$ & 17.66 & ----- & 12.71 & 43.58 & 43.71 & Medium sand \\
\hline & & $85-120$ & 18.00 & ----- & 30.97 & 26.30 & 42.73 & Coarse sand \\
\hline & \multirow{4}{*}{2} & $0-25$ & 17.66 & ----- & 30.65 & 26.37 & 42.98 & Coarse sand \\
\hline & & $25-50$ & 17.00 & ----- & 25.16 & 33.70 & 41.14 & Coarse sand \\
\hline & & $50-90$ & 17.33 & ----- & 37.61 & 23.52 & 38.87 & Coarse sand \\
\hline & & $90-120$ & 17.00 & ----- & 13.52 & 45.33 & 41.15 & Medium sand \\
\hline & \multirow{4}{*}{3} & $0-15$ & 16.66 & ----- & 31.54 & 22.72 & 45.74 & Coarse sand \\
\hline & & $15-80$ & 17.00 & ----- & 31.24 & 26.68 & 42.08 & Coarse sand \\
\hline & & $80-120$ & 16.66 & ----- & 31.84 & 28.84 & 39.32 & Coarse sand \\
\hline & & $120-150$ & 16.33 & ------ & 25.02 & 35.00 & 39.98 & Coarse sand \\
\hline & \multirow{4}{*}{4} & $0-15$ & 17.00 & ----- & 17.17 & 43.33 & 39.50 & Medium sand \\
\hline & & $15-60$ & 16.00 & ----- & 35.56 & 20.07 & 44.37 & Coarse sand \\
\hline & & $60-100$ & 16.00 & ----- & 36.12 & 22.09 & 41.79 & Coarse sand \\
\hline & & $100-150$ & 15.66 & ------ & 34.03 & 26.50 & 39.47 & Coarse sand \\
\hline & \multirow{4}{*}{5} & $0-29$ & 16.00 & ----- & 25.86 & 28.04 & 46.10 & Coarse sand \\
\hline & & $20-90$ & 16.33 & ----- & 35.17 & 28.17 & 36.66 & Coarse sand \\
\hline & & $90-120$ & 16.33 & ---- & 29.92 & 26.90 & 43.18 & Coarse sand \\
\hline & & $120-150$ & 16.33 & 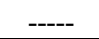 & 40.65 & 27.50 & 31.85 & Coarse sand \\
\hline \multirow{15}{*}{ 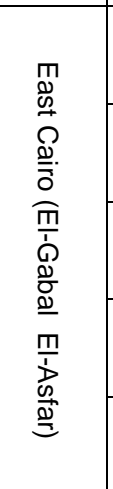 } & & $0-30$ & 18.33 & ----- & 19.08 & 52.26 & 28.66 & Medium sand \\
\hline & 1 & $30-90$ & 17.66 & ----- & 12.71 & 63.62 & 23.67 & Medium sand \\
\hline & & $90-120$ & 17.00 & ----- & 13.50 & 55.38 & 31.12 & Medium sand \\
\hline & & $0-50$ & 18.66 & 4.48 & 16.99 & 49.04 & 33.97 & Medium sand \\
\hline & 2 & $50-90$ & 18.21 & --- & 11.44 & 49.25 & 39.31 & Medium sand \\
\hline & & $90-150$ & 18.33 & ---- & 7.44 & 49.93 & 42.63 & Medium sand \\
\hline & & $0-50$ & 18.00 & --- & 23.15 & 49.81 & 27.04 & Medium sand \\
\hline & 3 & $50-100$ & 17.66 & ---- & 10.64 & 60.25 & 29.11 & Medium sand \\
\hline & & $100-150$ & 18.33 & ----- & 16.80 & 54.62 & 28.58 & Medium sand \\
\hline & & $0-30$ & 18.45 & ---- & 17.03 & 49.61 & 33.36 & Medium sand \\
\hline & 4 & $30-90$ & 18.33 & ---- & 9.03 & 66.00 & 24.97 & Medium sand \\
\hline & & $90--150$ & 18.33 & ---- & 13.69 & 57.64 & 28.67 & Medium sand \\
\hline & & $0-40$ & 18.66 & ----- & 16.63 & 50.36 & 33.01 & Medium sand \\
\hline & 5 & $40-80$ & 18.33 & 5.88 & 15.19 & 52.99 & 31.82 & Medium sand \\
\hline & & $80-150$ & 18.33 & ----- & 9.03 & 56.40 & 34.57 & Medium sand \\
\hline
\end{tabular}


Table (7). Chemical properties of soil samples at the three studied regions.

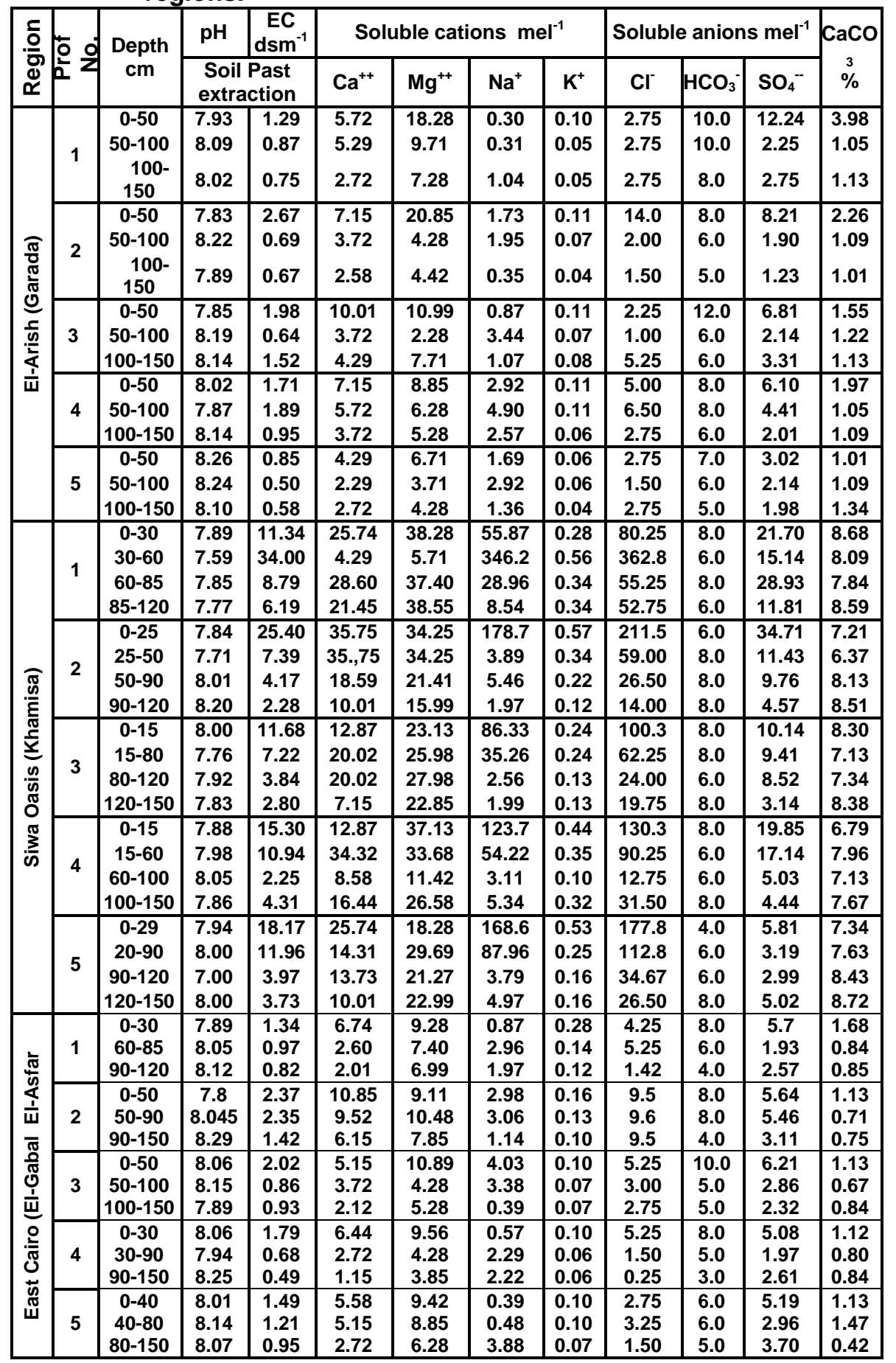


Table (8). Organic matter and available nutrients content in the soil surface layers of the three studied regions.

\begin{tabular}{|c|c|c|c|c|c|c|c|c|c|}
\hline \multirow{2}{*}{ Region } & \multirow{2}{*}{$\begin{array}{c}\text { Profile } \\
\text { No. }\end{array}$} & \multirow{2}{*}{ O.M. \% } & \multicolumn{7}{|c|}{ Available nutrients, $\mathrm{mgkg}^{-1}$} \\
\hline & & & $\mathbf{N}$ & $\mathbf{P}$ & $K$ & $\mathrm{Fe}$ & Mn & $\mathrm{Zn}$ & $\mathrm{Cu}$ \\
\hline \multirow{5}{*}{$\begin{array}{l}\text { El-Arish } \\
\text { (Garada) }\end{array}$} & 1 & 0.288 & 62.5 & 5.51 & 65.8 & 3.83 & 1.934 & 0.428 & 0.374 \\
\hline & 2 & 0.241 & 45.0 & 4.77 & 63.0 & 4.95 & 2.134 & 0.494 & 0.922 \\
\hline & 3 & 0.268 & 52.5 & 2.48 & 43.4 & 1.48 & 0.494 & 0.212 & 0.048 \\
\hline & 4 & 07 & 40.0 & 2.25 & 47.6 & 2.45 & 0.764 & 0.294 & 0.382 \\
\hline & 5 & 8 & 47.2 & 2.22 & 50.4 & 1.39 & 1.108 & 0.274 & 0.340 \\
\hline \multirow{5}{*}{$\begin{array}{c}\text { Siwa } \\
\text { Oasis } \\
\text { (Khamisa) }\end{array}$} & 1 & 0.220 & 55.0 & 2.19 & 114.8 & 2.51 & 0.240 & 0.184 & 0.006 \\
\hline & 2 & 0 & 52.5 & 1.47 & 133.0 & 3.38 & 0.138 & 0.256 & 0.156 \\
\hline & 3 & 0 & 35.0 & 1.53 & 116.2 & 4.08 & 0.138 & 0.284 & 0.266 \\
\hline & 4 & 00 & 32.5 & 1.73 & 116.2 & 1.49 & 0.172 & 0.298 & 0.114 \\
\hline & 5 & 0 & 35.0 & 1.76 & 124.6 & 3.52 & 0.108 & 0.124 & 0.108 \\
\hline \multirow{5}{*}{$\begin{array}{c}\text { East Cairo } \\
\text { (El-Gabal } \\
\text { El-Asfar) }\end{array}$} & 1 & 0.323 & 72.5 & 3.3 & 140.0 & 4.750 & 0.721 & 0.448 & 0.434 \\
\hline & 2 & 0.225 & 62.0 & 2.7 & 56.0 & 1.220 & 0.672 & 0.608 & 0.828 \\
\hline & 3 & 0.101 & 84.5 & 2.6 & 110.6 & 4.460 & 1.686 & 0.884 & 0.522 \\
\hline & 4 & 0.198 & 44.2 & 6.4 & 30.8 & 0.580 & 0.334 & 0.178 & 0.216 \\
\hline & 5 & 0.242 & 55.0 & 4.4 & 72.8 & 2.080 & 1.332 & 0.760 & 0.288 \\
\hline
\end{tabular}

- The available micronutrients contents, in surface layer, ranged from 1.39-4.95, 0.494-2.134, 0.212-0.494 and 0.048-0.922 $\mathrm{mgkg}^{-1}$ for Fe, Mn, Zn and $\mathrm{Cu}$, respectively. As for $(\mathrm{Fe}, \mathrm{Zn}$ and $\mathrm{Cu}$ ) contents are at lower or critical (marginal) level in the soils except the area that is represented by soil profile No. 2, the $\mathrm{Cu}$ content $(0.922)$ is adequate. The Mn content in the soil is adequate except soils that are represented by profiles No. 4 and 3 ; its content is low (0.494) and not sufficient (0.764) for plant growth. Some of these results are in agreement with those obtained by Aldabaa et al (2010).

b. Siwa Oasis (Khamisa):

- The soils are deep where the depth of soil profiles is ranging from 120 to $150 \mathrm{~cm}$ followed by the water table, except at the area that represented by soil profiles No. 1 and 3.

- $\quad$ Saturation percent (SP) was low where it ranged from 15.66 to $18.33 \%$ with an average of $16.83 \%$. The soils are course texture (medium to coarse sand).

- $\quad$ The soils are slightly to moderately alkaline as $\mathrm{pH}$ values ranged from 7.00 to 8.20 with an average of 7.85 .

- The soils are slightly to extremely saline as EC values ranged from 2.25 to $34.00 \mathrm{dSm}^{-1}$ with an average of $9.79 \mathrm{dSm}^{-1}$

- The soils are moderately calcareous as $\mathrm{CaCO}_{3} \%$ is ranged from 6.37$8.72 \%$ with an average of $7.81 \%$.

- The cationic and the anionic sequence is as follows:

$$
{ }^{*} \mathrm{Na}^{+} \text {and } / \text { or } \mathrm{Mg}^{++}>\mathrm{Ca}^{++}>\mathrm{K}^{+} \quad{ }^{*} \mathrm{Cl}^{-}>\mathrm{SO}_{4}^{--}>\mathrm{HCO}_{3}{ }^{-}
$$

- $\quad$ O.M. content, in surface layer, is low as it ranges from 0.100 to $0.230 \%$ with an average of $0.194 \%$.

- The available macronutrients content, in surface layer, is not sufficient or marginal for the plant requirements to grow, as it ranged from 32.5-55.0, 
1.47-2.19 and 114.8-133.0 $\mathrm{mgkg}^{-1}$ for $\mathrm{N}, \mathrm{P}$ and $\mathrm{K}$ respectively. The available micronutrients content, in surface layer, is at low level in the soils as they range from 1.49-4.08, 0.108-0.240, 0.124-0.298 and $0.004-0.266 \mathrm{mgkg}^{-1}$ for $\mathrm{Fe}, \mathrm{Mn}, \mathrm{Zn}$ and $\mathrm{Cu}$, respectively. These results are in agreement with those obtained by Abd El Fattah and Dahmash ( 2002 ).

\section{c. East Cairo (El-Gabal El-Asfar):}

- The soils are course texture (medium sand).

- Saturation percent (SP) was low where it ranged from 17.00 to $18.66 \%$ with an average of $18.77 \%$.

- The soils are moderately alkaline as $\mathrm{pH}$ values ranged from 7.80 to 8.29 with an average of 8.05 .

- The soils are free saline as EC values ranged from 0.49 to $2.37 \mathrm{dSm}^{-1}$ with an average of $1.31 \mathrm{dSm}^{-1}$.

- The soils are none calcareous as $\mathrm{CaCO}_{3} \%$ ranged from $0.42-1.68 \%$ with an average of $0.96 \%$.

- The cationic and the anionic sequences is as follows:

$$
{ }^{*} \mathrm{Mg}^{++}>\mathrm{Ca}^{++}>\mathrm{Na}^{+}>\mathrm{K}^{+} \quad{ }^{*} \mathrm{HCO}_{3}^{-}>\mathrm{Cl}^{-}>\mathrm{SO}_{4}^{--}
$$

- O.M. content, in surface layer, is low as it ranged from 0.101 to $0.323 \%$ with an average of $0.218 \%$.

- The available macronutrients content, in surface layer, is not sufficient or marginal for the plant requirements to grow, as it ranged from 44.2-84.5, 2.60-6.40 and 30.8-140.0 $\mathrm{mgkg}^{-1}$ for $\mathrm{N}, \mathrm{P}$ and $\mathrm{K}$, respectively.

- The available micronutrients content, in surface layer, is sufficient for plant requirements as it ranged from $0.58-4.75,0.334-1.686,0.178-0.884$ and $0.216-0.828 \mathrm{mgkg}^{-1}$ for $\mathrm{Fe}, \mathrm{Mn}, \mathrm{Zn}$ and $\mathrm{Cu}$, respectively.

Some of these results are in agreement with those obtained by Aldabaa et al. (2010).

3. Statistical analysis for the results of some chemical soil properties in the soil surface layers of the three studied regions.

a. Comparison among the three studied regions

Results in Table (9) shows that there were no significant differences between El Arish (Garada) region, and East Cairo (El-Gabal El-Asfar) region for pH, $E C$, cations and anions in saturated paste extract of soil surface layer.

Table (9). Statistical analysis for some chemical soil properties of the three studied regions

\begin{tabular}{|c|c|c|c|c|c|c|c|c|c|c|}
\hline Region & $\mathbf{p H}$ & $\mathbf{E C}$ & $\mathbf{C a}^{++}$ & $\mathbf{M g}^{++}$ & $\mathbf{N a}^{+}$ & $\mathbf{K}^{+}$ & $\mathbf{C l}$ & $\mathbf{H C O}_{3}$ & $\mathbf{S O}_{4}^{--}$ & $\mathbf{C a C O}_{3} \%$ \\
\hline $\mathbf{1}$ & $7.978 \mathrm{a}$ & $1.700 \mathrm{~b}$ & $6.952 \mathrm{~b}$ & $13.136 \mathrm{~b}$ & $1.502 \mathrm{~b}$ & $0.098 \mathrm{~b}$ & $5.350 \mathrm{~b}$ & $9.00 \mathrm{a}$ & $7.276 \mathrm{~b}$ & $2.154 \mathrm{~b}$ \\
$\mathbf{2}$ & $7.910 \mathrm{~b}$ & $16.378 \mathrm{a}$ & $22.594 \mathrm{a}$ & $30.214 \mathrm{a}$ & $122.64 \mathrm{a}$ & $0.412 \mathrm{a}$ & $140.03 \mathrm{a}$ & $6.80 \mathrm{c}$ & $18.442 \mathrm{a}$ & $7.664 \mathrm{a}$ \\
$\mathbf{3}$ & $7.964 \mathrm{ab}$ & $1.802 \mathrm{~b}$ & $7.684 \mathrm{~b}$ & $9.652 \mathrm{c}$ & $1.768 \mathrm{~b}$ & $0.148 \mathrm{~b}$ & $5.400 \mathrm{~b}$ & $8.00 \mathrm{~b}$ & $5.564 \mathrm{~b}$ & $1.238 \mathrm{c}$ \\
\hline LSD $_{0.05}$ & 0.063 & 1.919 & 3.465 & 3.302 & 18.26 & 0.063 & 18.13 & 0.52 & 3.750 & 0.361 \\
\hline
\end{tabular}

While there were significant differences between these two regions and Siwa Oasis (Khamisa) region. The highest values were observed in Siwa Oasis (Khamisa) region with the exception of highest values for $\mathrm{pH}$ and $\mathrm{HCO}_{3}$, which were present in the El Arish (Garada) region. 
Generally, it is clear from the results in Table (10) that there were significant differences between the under studied three regions and each other in the content of organic matter (O.M.) and available macro- and micronutrients in the soil surface layer.

Table (10). Statistical analysis for some chemical properties of soil surface layers in the three studied regions

\begin{tabular}{|c|c|c|c|c|c|c|c|c|c|}
\hline \multirow{2}{*}{\multicolumn{2}{|c|}{$\begin{array}{c}\text { Chemical soil } \\
\text { properties }\end{array}$}} & \multirow{2}{*}{ O.M.\% } & \multicolumn{7}{|c|}{ Available nutrients in $\mathrm{mgkg}^{-1}$} \\
\hline & & & $\mathbf{N}$ & $\mathbf{P}$ & $\mathbf{K}$ & $\mathrm{Fe}$ & Mn & $\mathbf{Z n}$ & $\mathrm{Cu}$ \\
\hline \multirow{3}{*}{ Region } & 1 & 0.2 & $49.440 \mathrm{~b}$ & $3.400 \mathrm{a}$ & $54.04 \mathrm{c}$ & $2.820 \mathrm{a}$ & $1.287 a$ & $0.340 \mathrm{~b}$ & $0.413 b$ \\
\hline & 2 & 0. & $42.000 \mathrm{c}$ & $1.740 \mathrm{~b}$ & $120.96 a$ & $2.996 a$ & $59 b$ & $0.229 b$ & $0.130 \mathrm{~b}$ \\
\hline & 2 & 0.2 & $63.640 \mathrm{a}$ & $3.880 a$ & $82.04 b$ & $2.618 a$ & $0.949 a$ & $0.776 \mathrm{a}$ & $1.458 \mathrm{a}$ \\
\hline \multicolumn{2}{|c|}{ LSD 0.05} & ${ }_{0}$ & 5.341 & 2.110 & 15.78 & 0.921 & 0.349 & 0.243 & 0.526 \\
\hline \multicolumn{3}{|c|}{$=$ El-Arish (Gara } & \multicolumn{3}{|c|}{ 2= Siwa Oasis (Khamisa) } & \multicolumn{4}{|c|}{ 3= East Cairo (El-Gabal El-Asfar) } \\
\hline
\end{tabular}

Also, it can be noticed that there was no significant difference in the content of organic matter and nutrients between El Arish (Garada) region, and East Cairo (El-Gabal El-Asfar), except that in the case of nitrogen, $\mathrm{K}, \mathrm{Zn}$ and $\mathrm{Cu}$, significant differences have been found. As for the content of the surface layer of $\mathrm{Fe}$, there were no significant differences in the three regions. On the other hand, the highest values of both O.M. and $\mathrm{Mn}$ in the El Arish (Garada) region have been present, while existed the highest values N, P, Zn and $\mathrm{Cu}$ in East Cairo (El-Gabal El-Asfar). As for the $\mathrm{K}$, its highest value in was noticed in Siwa Oasis (Khamisa) region.

\section{b. Multiple correlation between some chemical soil properties in the three studied regions}

Table (11) shows the muliple correlation between the $\mathrm{pH}$, EC, cations and anions in soil saturated paste extract of the surface layer in the three studied regions.

For $\mathrm{pH}$, there was a significant negative correlation between $\mathrm{pH}$ and the $\mathrm{EC}, \mathrm{K}$, and $\mathrm{HCO}_{3}$, but positive $\mathrm{CaCO}_{3} \%$, and highly significant negative correlation between $\mathrm{pH}, \mathrm{Ca}^{++}$and $\mathrm{SO}_{4}^{--}$. It is also observed that there is no significant correlation between $\mathrm{pH}$ and each of $\mathrm{Na}^{+}$and $\mathrm{Cl}^{-}$.

As for each of the $\mathrm{EC}, \mathrm{Ca}, \mathrm{Mg}, \mathrm{Na}, \mathrm{K}, \mathrm{Cl}, \mathrm{HCO}_{3}, \mathrm{SO}_{4}, \mathrm{CaCO}_{3} \%$, it has been observed a highly significant positive correlation with each other but it was found highly significant negative correlation in the case of $\mathrm{HCO}_{3}$, besides, it was not noticed a significant correlation between $\mathrm{HCO}_{3}$ and both $\mathrm{Mg}$ and $\mathrm{SO}_{4}$.

Table (12) shows the multiple correlation between each of the content of organic matter and available nutrients in the soil surface layer of the three studied regions. 
Table (11): Multiple correlation for $\mathrm{pH}, \mathrm{EC}, \mathrm{CaCO}_{3} \%$ and cation and anion in the three studied regions

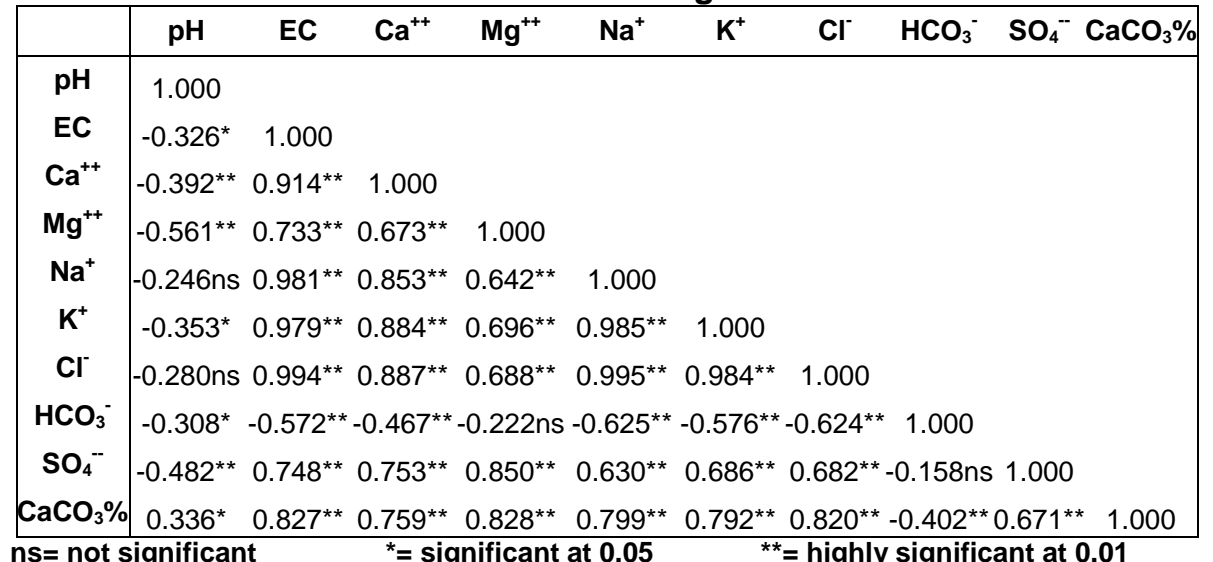

Table (12): Multiple correlation for organic matter (O.M.) and available nutrients in the three studied regions

\begin{tabular}{|c|c|c|c|c|c|c|c|c|}
\hline & O.M. & $\mathbf{N}$ & $\mathbf{P}$ & $\mathbf{K}$ & $\mathrm{Fe}$ & Mn & $\mathrm{Zn}$ & $\mathrm{Cu}$ \\
\hline O.M. & 1.000 & & & & & & & \\
\hline $\mathbf{N}$ & $-0.114 n s$ & 1.000 & & & & & & \\
\hline $\mathbf{P}$ & $0.015 \mathrm{~ns}$ & $0.236 \mathrm{~ns}$ & 1.000 & & & & & \\
\hline K & $0.377^{*}$ & $0.120 \mathrm{~ns}$ & $-0.340^{*}$ & 1.000 & & & & \\
\hline $\mathrm{Fe}$ & $0.207 \mathrm{~ns}$ & $0.313^{*}$ & $0.124 \mathrm{~ns}$ & $0.567^{* *}$ & 1.000 & & & \\
\hline Mn & $-0.182 n s$ & $0.471^{* *}$ & $0.569^{* *}$ & $-0.342^{*}$ & $0.397^{* *}$ & 1.000 & & \\
\hline $\mathrm{Zn}$ & $-0.408^{* *}$ & $0.724^{\star *}$ & $0.019 \mathrm{~ns}$ & $0.107 \mathrm{~ns}$ & $0.337^{\star}$ & $0.553^{\star *}$ & 1.000 & \\
\hline $\mathrm{Cu}$ & $-0.366^{*}$ & $0.621^{* *}$ & $0.007 \mathrm{~ns}$ & $0.023 n s$ & $0.268 \mathrm{~ns}$ & $0.578^{* *}$ & $0.951^{\star *}$ & 1.000 \\
\hline
\end{tabular}

It was noted that no significant correlation was observed between organic matter (O.M.) content and each of available N, P, Fe and Mn, while a significant correlation was found with available $\mathrm{K}$ and available $\mathrm{Cu}$, where it was positive with $\mathrm{K}$ but negative with $\mathrm{Cu}$. Also, it was noticed a highly negative correlation between O.M. and the available $\mathrm{Zn}$.

With regard to available nitrogen $(\mathrm{N})$, it was noted a highly positive significant correlation between $\mathrm{N}$ and each of available $\mathrm{Mn}, \mathrm{Zn}$ and $\mathrm{Cu}$ and only positive significant with available Fe. However, available nitrogen was not correlated significantly with either available $\mathrm{P}$ or $\mathrm{K}$.

Finely, there was no significant correlation between available $\mathrm{P}$ and each of available $\mathrm{Fe}, \mathrm{Zn}$ and $\mathrm{Cu}$, as well as between available $\mathrm{K}$ and each of available $\mathrm{Zn}$ and $\mathrm{Cu}$. However, there was a significant negative correlation between available $\mathrm{K}$ and each of available $\mathrm{P}$ and $\mathrm{Mn}$. While, there was a highly significant positive correlation between both available $\mathrm{P}$ and $\mathrm{Mn}$, as well as between both available $\mathrm{K}$ and Fe. On the other hand, it was observed 
highly significant positive correlation between available micronutrients and each other.

\section{CONCLUSION}

From vegetation studies, it was concluded that El Arish region was semi fixed (more or less stabilized) dune area. It is dominated by Artemisia monsperma. In Siwa Oasis, the phreatophytic species Alhagi maurorum (=A. graecarum) dominates the extensions where sand embankments are mostly stabilized as well as extensions veneered with sand sheets. With regard to East Cairo (El Gabal El Asfar areas, a total of 25 species (20 perennials and 5 annuals) were recorded at El Gabal El Asfar. Sand dune habitat in the study area is divided into three microhabitats namely: Interdunal, Dune crest, and Leeward habitat.

Regarding soil fertility status of the three studied regions, data indicated that the soils texture is sand in all regions, but it ranges from medium to coarse in Siwa Oasis (Khamisa), medium in East Cairo (El-Gabal El-Asfar) and very fine in El-Arish (Garada). The soil saturation percent (SP) and total organic matter (O.M.) content are low and the available macronutrients content (NPK), is not sufficient for the plant requirements to grow in all regions. Available micronutrients content ( $\mathrm{Fe}, \mathrm{Zn}$ and $\mathrm{Cu}$ ), in surface layer, contents are at lower or critical (marginal) level in soils of both Garada and Khamisa regions, whereas, in El-Gabal El-Asfar, available micronutrients are sufficient for plant requirement. Garada soils are moderately alkaline, free saline and rarely slightly, varied from none to slightly calcareous, the cationic and the anionic sequences are as follows: $\mathrm{Mg}^{++}>\mathrm{Ca}^{++}>\mathrm{Na}^{+}>\mathrm{K} ; \mathrm{HCO}_{3}>\mathrm{SO}_{4}^{--}>\mathrm{Cl}^{-}$. Khamisa soils are s slightly to moderately alkaline, slightly to extremely saline, moderately calcareous, the cationic and the anionic sequences is as follows: $\mathrm{Na}^{+}$and $/ \mathrm{or} \mathrm{Mg}^{++}>\mathrm{Ca}^{++}>\mathrm{K}^{+}$; $\mathrm{Cl}^{-}>\mathrm{SO}_{4}{ }^{--}>\mathrm{HCO}_{3}{ }^{-}$. El-Gabal El-Asfar soils are free saline, none calcareous, the cationic and the anionic sequences is as follows: $\mathrm{Mg}^{++}>\mathrm{Ca}^{++}>\mathrm{Na}^{+}>\mathrm{K}^{+}$; $\mathrm{HCO}_{3}{ }^{-}>\mathrm{Cl}^{-}>\mathrm{SO}_{4}^{-}$.

Statistical analysis indicated that significant differences were observed between the under studied three regions and each other in the content of organic matter (O.M.) and available macro- and micro-nutrients in the soil surface layer. The relationship between $\mathrm{pH}, \mathrm{EC}$, cations and anions, in soil saturated paste extract of the surface layer in the three studied regions, was showed through multiple correlations.

\section{REFERENCES}

Abd El Fattah, R. I. and A. M. Dahmash (2002). Plant and soil relationships in the North - Eastern Desert, Egypt. Egyptian J. Desert. Res., 52, No. $1: 1-20$.

Aldabaa, A.A, Hailin Zhang, A. Shata, S. El-Sawey, A. Abdel-Hameed, J. L. Schroder (2010).Land Suitability Classification of a Desert Area in Egypt for Some Crops Using Microleis Program. American-Eurasian J. Agric. \& Environ. Sci., 8 (1): 80-94. 
Ali, M. E. (2004). Studies On the Ecology of Sinai Peninsula. M.Sc.Thesis, Mansoura Univ., 180pp.

Ayyad, M. A. and A. M. Fakhry (1994). Species diversity in the Plant Communities of the coastal dunes of the Western Mediterranean desert of Egypt. J. of Union of Arab Biol., 1 (B) : 73-87 .

Ayyad, M. A. and A. M. Fakhry (1996). Plant brodiversity in the western Mediterranean desert of Egypt. Verhandlungen der Gesellschaft fur Okologie, Baind 25:65-76.

Bashour, I.I. and A.H. Sayegh (2007). Methods of Analysis for Soils of Arid and Semi-Arid Region, American University of Beirut, Lebanon. FAO, Rome.

Boulos, L. (1995). Flora of Egypt: a Checklist. Al-Hadara Publishing, Cairo, Egypt, $283 \mathrm{pp}$.

Danin, A. (1983). Desert Vegetation of Israel and Sinai. Jerusalem, Cana publishing house. 148pp.

EL- Ghareeb, R. (1991). Vegetation and soil changes induced by Mesembryanthemum crystallinum L. in a Mediterranean desert ecosystem. J. Arid Envi , 20:321-330.

El- Khouly, A.A. (2001). Plant diversity in the dry land habitats of Siwa Oasis , Western Desert, Egypt . J. Environ . Sci., 22 : 125- 143.

Embabi, N.S. (2000). Sand dune in Egypt. In sedimentary geology of Egypt applications and economies. Part 1, special publication, The Sediment logical Society of Egypt, Cairo, p. 45-87.

FAO (2006). Guideline for soil description, Fourth Edition. Rome.

Gavlak R, D. Horneck, R.O. Miller and J. Kotuby-Amacher (2003). Soil, Plant and Water Reference Methods for the Western Region, $2^{\text {nd }}$ ed. WCC103 Publication, Colorado State University, Ft. Collins, Colorado, USA.

Hegazi, A., I. H. El Bagouri and M. A. Kassas (2002). National action plan for combating desertification processes. Cairo, April, 2002.

Hegazi, A.M., M.Y. Afifi, M.A. EL Shorbagy, A.A. Elwan and S. ElDemerdashe (2005).Egyptian National Action Program To Combat Desertification. ARAB REPUBLIC OF EGYPT, Ministry of Agriculture and Land Reclamation, Desert Research Center.

Piper, C.S. (1950). "Soil and plant analysis." Inter. Sci. Pub., Inc. New York, 360-370.

Misak , R. F. and M. Y. Draz (1997). Sand drift control of selected coastal and desert dunes in Egypt: Case studies. J. Arid Envoi.,35:17-28.

Misak, R. F. and M. M. El Ghazawy (1989). Desertification Processes in the Sinai Peninsula, Egypt. International Meeting on Environmental Disasters and Desertification, Palermo, Italy, 6-8 June, 1989.

SAS Institute (1996). SAS user's guide. $3^{\text {rd }}$ ed. SAS Inst., Cary, NC.

Täckholm, V. (1974). Students' Flora of Egypt. $2^{\text {nd }}$ edn. Cairo University Publications, Cooperative Printing Company, Beirut. 888 pp.

Tsoar, H. (1995). Desertification in Northern Sinai in the Eighteenth Century. Climatic change, 29:429-438.

[USDA] US Department of Agriculture. (2004).Data: Crop production practices.(6 August, 2004)

Zahran (1972). On the ecology of Siwa Oasis. Egypt. J. Bot. 15: 223-242. 
Zahran, M. A. and A.J. Willis (2009). "The Vegetation of Egypt." London 2 nd edition, Springer Publisher, Netherlands, $437 \mathrm{pp}$.

دراسات على الخواص البيئية والخصوبية لبعض أنواع الأراضى الصحراوية في مصر عبدالله قاسم زغلول1 ، أسماء عبده شطا2 ، محرم فؤاد عطية3 و السيد على محمد خليفة4 عاله 1 قسم الكثبان الرملية , مركز بحوث الصحراء , القاهرة

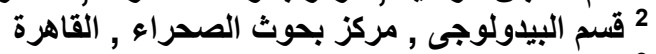

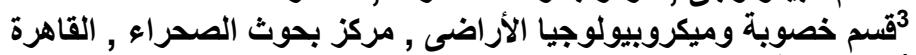

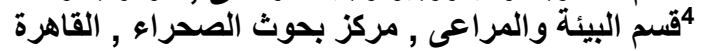

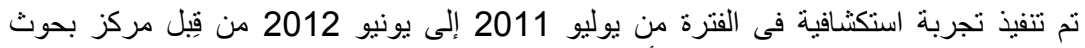

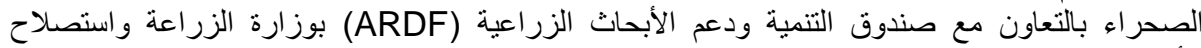

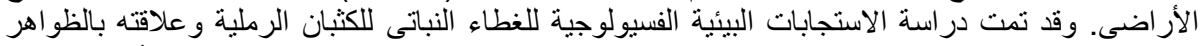

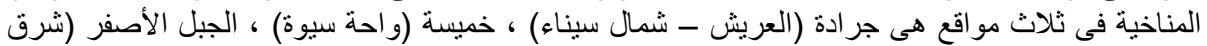

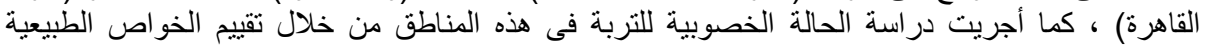

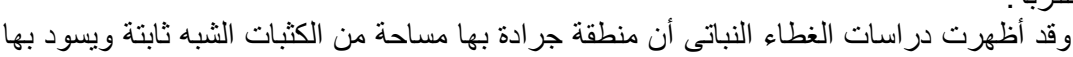
و الكيميائية للنربة.

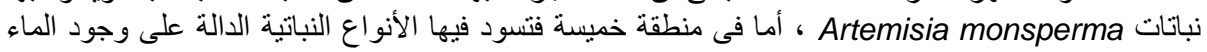

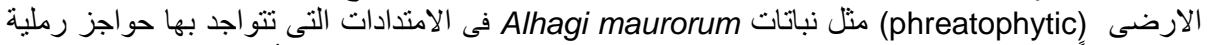

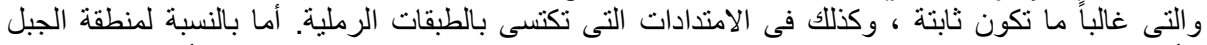

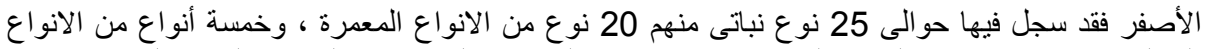

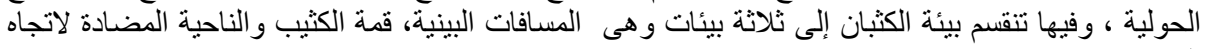

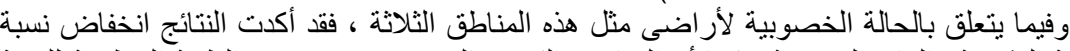

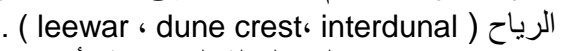

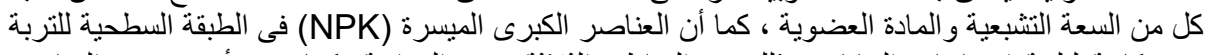

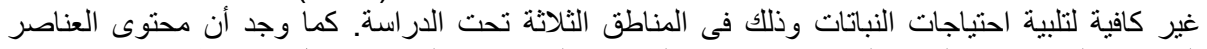

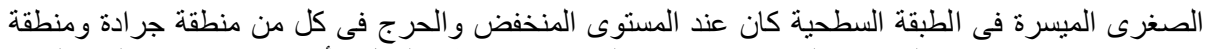

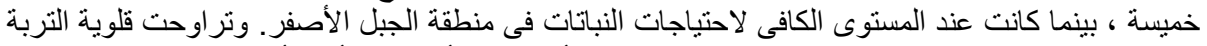

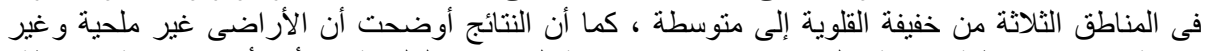

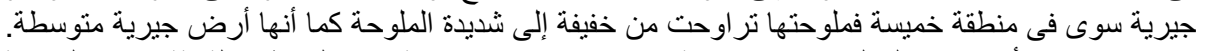

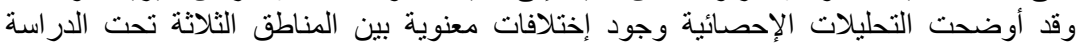

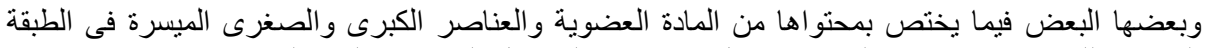

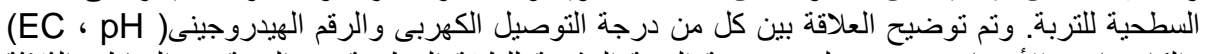

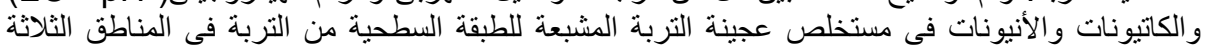
المدروسة وذللك من خلال الارنباط المتعدد.

\author{
كلية الزراعة - جامعة المنصورة

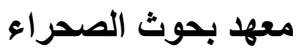

\author{
قام بتحكيم البحث

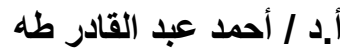

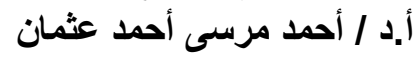

